\title{
Editorial Comment: Oncological and functional outcomes of open versus laparoscopic partial nephrectomy in T1b tumors: A single-center analysis
}

\author{
Luciano A. Favorito ${ }^{1,2}$ \\ ${ }^{1}$ Professor Associado da Unidade de Pesquisa Urogenital - Universidade do Estado de Rio de Janeiro - Uerj, \\ Rio de Janeiro, RJ, Brasil, ${ }^{2}$ Serviço de Urologia, Hospital Federal da Lagoa, Rio de Janeiro, RJ, Brasil
}

\section{COMMENT}

Kartal and Collegues from Turkey in this important paper studied the oncological and functional results of open partial nephrectomy (OPN) and laparoscopic partial nephrectomy (LPN) at the T1b clinical stage in 63 patients and compared 41 submitted to OPN and 22 submitted to LPN (1). The authors observed that there are no differences between OPN and LPN techniques between oncological and functional outcomes in patients with clinical stage T1b RCC.

Partial nephrectomy (open, laparoscopic or robotic) is considered the gold standard for treating localized renal tumors (2-6). In last years important technical improvements were introduced with robotic surgery. Recently a interesting study suggested that the robotic technique is a valid option for partial nephrectomy, especially for PADUA<10 lesions but without differences between surgical techniques in more complex masses (7). The present paper confirms previous findings (8-10) that open and laparoscopic surgery still has indications in complex cases and (because the robotic costs) in countries in development.

\section{CONFLICT OF INTEREST}

None declared.

\section{REFERENCES}

1. Kartal I, Karakoyunlu N, Çakici Ç, Karabacak O, Sağnak L, Ersoy H. Oncological and functional outcomes of open versus laparoscopic partial nephrectomy in T1b tumors: A singlecenter analysis. Int Braz J Urol. 2020;46: 341-50.

2. Volpe A, Cadeddu JA, Cestari A, Gill IS, Jewett MA, Joniau S, et al. Contemporary management of small renal masses. Eur Urol. 2011;60:501-15.

3. Porreca A, D'Agostino D, Dente D, Dandrea M, Salvaggio A, Cappa E, et al. Retroperitoneal approach for robot-assisted partial nephrectomy: technique and early outcomes. Int Braz J Urol. 2018;44:63-8.
4. Lanchon C, Arnoux V, Fiard G, Descotes JL, Rambeaud JJ, Lefrancq JB, et al. Super-selective robot-assisted partial nephrectomy using near-infrared flurorescence versus early-unclamping of the renal artery: results of a prospective matched-pair analysis. Int Braz J Urol. 2018;44:53-62.

5. Tachibana H, Takagi T, Kondo T, Ishida H, Tanabe K. Comparison of perioperative outcomes with or without renorrhaphy during open partial nephrectomy: A propensity score-matched analysis. Int Braz J Urol. 2018;44:467-74.

6. Bertolo R, Fiori C, Piramide F, Amparore D, Porpiglia F. The preoperative stratification of patients based on renal scan data is unable to predict the functional outcome after partial nephrectomy. Int Braz J Urol. 2018;44:740-9. 
7. Bravi CA, Larcher A, Capitanio U, Mari A, Antonelli A, Artibani $W$, et al. Perioperative Outcomes of Open, Laparoscopic, and Robotic Partial Nephrectomy: A Prospective Multicenter Observational Study (The RECORd 2 Project). Eur Urol Focus. 2019;11. pii: S2405-4569(19)30335-9. [Epub ahead of print].

8. Zapala P, Dybowski B, Miazek N, Radziszewski P. Open partial nephrectomy for entirely intraparenchymal tumors: a matched case-control study of oncologic outcome and complication rate. Int Braz J Urol. 2017:43:209-15.
9. Tsivian M, Tsivian E, Stanevsky Y, Bass R, Sidi AA, Tsivian A Laparoscopic partial nephrectomy for tumors $7 \mathrm{~cm}$ and above. Perioperative outcomes. Int Braz J Urol. 2017;43:857-62.

10. Kaygisiz 0 , Çelen S, Vurușkan BA, Vurușkan H. Comparison of two different suture techniques in laparoscopic partial nephrectomy. Int Braz J Urol. 2017;43:863-70.

ARTICLE INFO

(iD) Luciano A. Favorito

http://orcid.org/0000-0003-1562-6068

Int Braz J Urol. 2020; 46: 351-2

Submitted for publication:

January 30, 2020

Unidade de Pesquisa Urogenital

da Universidade do Estado de Rio de Janeiro - UERJ,

Rio de Janeiro, RJ, Brasil

E-mail: lufavorito@yahoo.com.br
Accepted after revision:
February 05, 2020 